\title{
Erratum to: Modified technique of levator plication for the correction of Marcus Gunn jaw-winking ptosis: a case series
}

Mandeep Singh Bajaj - Dewang Angmo •

Neelam Pushker • Maya Hada

Published online: 8 April 2015

(C) Springer Science+Business Media Dordrecht 2015

Erratum to: Int Ophthalmol

DOI 10.1007/s10792-015-0060-z

The Category of this paper is wrong. It should read:

Case report.

The online version of the original article can be found under doi:10.1007/s10792-015-0060-z.

M. S. Bajaj · D. Angmo $(\bowtie) \cdot$ N. Pushker · M. Hada

Oculoplasty and Paediatric Ophthalmology Services,

Department of Ophthalmology, Dr. Rajendra Prasad

Centre for Ophthalmic Sciences, All India Institute of

Medical Sciences, New Delhi, India

e-mail: dewang45@gmail.com 